\title{
Impact of health and safety on human resource in construction industry
}

\author{
Belal A. Shaban ${ }^{1^{*}}$, Abdirahman Jibril ${ }^{1}$ \\ ${ }^{1 *}$ Civil Engineering Department, Near East University, Nicosia, Via Mersin 10, Turkey
}

ARTICLE INFO

ARTICLE HISTORY:

Received: 2 July 2021

Revised: 17 September 2021

Accepted: 18 December 2021

Published: 31 January 2022

\section{KEYWORDS:}

Construction industry, human resource, health and safety, Gaza strip

\section{A B S T R A C T}

The construction industry has long been regarded as one of the most vital in a country's economy due to its wide links with other sectors, regarding human resources are the most important source in the construction sector. very few companies have the ability to exploit this resource and provide facilities of health and safety and protect workers to avoid risks. This study aims to assess the impact of health and safety in the construction industry on human resources and to study the factors associated with the causes of construction worker dissatisfaction. To achieve the objectives of the study, the quantitative and qualitative method was used, whereby a questionnaire was used to find out the impact of health and safety on workers in the construction sector in Gaza Strip. The study concluded with the satisfaction of construction workers about the nature of the relationship between them and their employers, which is characterized by passion and solidarity. The construction companies lack a system that depends on providing pensions, vacations, insurances, and bonuses to workers within these companies. Health and safety standards are ranked first in terms of the interest of workers and employers, which indicates their importance in the field of work and the extent of its impact on it.

\section{INTRODUCTION}

Health and safety topic gains importance in the construction sector. Its appearance in many aspects of human life cannot be ignored. The construction sector is very important in many countries of the world developing or developed, due to its impact on the economy. The construction industry is exposed to many types of hazards and accidents due to the diverse nature that it contains (Davis \& Thomasin, 1996). it ranks high among the various industries with the incidence of injuries and disabilities, in addition to containing the highest deaths in workers. (Khalid, 1996) agrees that the construction industry is high in injuries and deaths compared to other industries. The issue of health and safety is of great importance in the field of construction because of the volatile nature it contains, in addition, we cannot ignore health and safety in various industries and sectors.

Many research studies have emphasized the importance of health and safety in the construction sector. Safety in construction includes the safety of employees and workers and working in a safe and secure environment. Working in a safe environment helps employees achieve increased profitability, productivity and lower operating costs (Levitt \& Samelson, 1993). Hazards at construction sites affect the safety and health of workers and increase the likelihood of accidents and worker deaths ( $\mathrm{Ng}$ et al., 2005).

\section{LITERATURE REVIEW}

The complicated nature of projects has necessitated the creation of programs in the construction industry to acquire effective abilities in delegating project management tasks to the appropriate personnel in order to assure the process's success. To detect personnel traits, companies adopt unbiased methodologies (Madter et al., 2012). Human resource refers to the organization's human aspect, or the combination of intelligence, skills, and expertise (Bontis et al.,1999). Individuals capable of learning, adapting, innovating, and providing the creative push that, if properly motivated, can ensure the organization's long-term survival are known as human resource (Armstrong, 2006). whereas Human Resource Development is the integration of 
individual, career, and organizational development responsibilities in order to maximize organizational members' productivity, quality, opportunity, and fulfilment as they strive to achieve the organization's goals (Nassazi, 2013). the success of any institution is related to the skills, knowledge, and experience of employees, that often achieved through the development of human resources at the institution (Gberevbie, 2012). Human resources focuse what the human adds to the success equation, both personally and organizationally, whereas Individual and organizational for learning, and performance are two main strands for Human Resource Development (Swanson et al., 2001). Since the human factor is one of the factors that use an organization's resources effectively remain the most valuable (Uzondu, 2013). The researchers confirmed that human development led to enhancing and improving the performance of the organization (Tabassi et al., 2011). However, there are very few companies that have the ability to make optimal use of this resource (Ahmad \& Schroeder, 2003). The optimal recruitment of human resources is very important for the organization in order to achieve its goals and tasks (Ahmed \& Akhtar, 2012). The construction industry's diversified character exposes its staff to a wide range of hazards (Davies \& Tomasin, 1996). resulting in serious casualties and illnesses on a daily basis. (Davies \& Tomasin, 1996). it is one of the most dangerous sectors on the planet. (Jannadi \& Bu-Khamsin, 2002). and has a high rate of casualties when compared to other sectors (Khalid, 1996). this risking the health \& wellbeing of staff. ( $\mathrm{Ng}$ et al., 2005). Safety is important, involves protecting the wellbeing of workers and ensuring that they operate in a safe and healthy workplace. According to empirical data, a safe workplace aids employees in increasing productivity, improve revenue, and lower operational costs (Levitt \& Samelson, 1993).

The concept of health and safety focuses on the security, preservation, and well-being of workers (Yip et al.,2005). that include both psychological and physical wellbeing at the construction sites (Kheni et al., 2008). that's mean it is clear of bodily and mental sickness (Rantanen \& Fedotov, 1998). The inability of personnel to follow working procedures recommended and supervised by the board and fatalities (Hamid et al., 2008). casualties can occur as an outcome of dangerous acts or workplace environments (Kartam \& Bouz, 1998). or the absence of strategies and policies in construction companies in safety (Hamid et al., 2008).

However Human resources can develop policies and strategies that ensure a safe work environment for employees and workers and reduce accidents and take action immediately (Umrani, 2016). By training workers and employees on safety as the number of accidents decreased when employees and workers felt that their roles were safe (Lin \& Mills, 2001). workers and employees must have the appropriate skills and knowledge (Law et al.,2006). executive authorities is the leading cause of construction

That facilitates their work. risks and accidents can be reduced in construction sites by identifying appropriate and preventive methods for using machines and equipment in the correct way (Cooper \& Cotton, 2000). However bad training cause to increase in the rate of injury and accidents during Work (Cox \& Cox, 1996).

\section{METHODOLOGY}

A literature review is presented about role of human resource in health and safety in the construction industry. The sources have mainly been referred to books, conferences, academic research, and theses. A questionnaire was used as the main tool to collect the data in one of Palestinian construction site in Gaza city, to achieve the objective of the research, that included a set of questions to assessing the current situation of health and safety in the construction sector. The questions of questionnaire were explored through several previous studies. Likert scale of 1-5 was employed in the questionnaire, that is a form of psychometric response scale and is the scale most frequently used in the studies. When Respondents answer a questionnaire by Likert scale, they demonstrate their level of agreement with the claims.

\section{RESULTS AND DISCUSSIONS}

Table 1. Respondent's Profile

\begin{tabular}{|c|c|c|c|}
\hline $\begin{array}{c}\text { Respondent's } \\
\text { data }\end{array}$ & Categories & Frequency & $\begin{array}{c}\text { Percent } \\
\%\end{array}$ \\
\hline \multirow{2}{*}{ Gender } & 60 & 100.0 & 60 \\
\cline { 2 - 4 } & 0 & 0.0 & 0 \\
\hline \multirow{4}{*}{ Age } & $<25$ & 23 & 38.3 \\
\cline { 2 - 4 } & $25-30$ & 18 & 30.0 \\
\cline { 2 - 4 } & $30-40$ & 10 & 16.7 \\
\cline { 2 - 4 } Experience in & More than 40 & 9 & 15.0 \\
\cline { 2 - 4 } field & $<5$ & 23 & 38.3 \\
\cline { 2 - 4 } & $5-10$ & 17 & 28.3 \\
\cline { 2 - 4 } & More than 15 & 6 & 10.0 \\
\hline \multirow{3}{*}{$\begin{array}{c}\text { Education } \\
\text { level }\end{array}$} & None & 1 & 23.3 \\
\cline { 2 - 4 } & Primary level & 7 & 11.7 \\
\cline { 2 - 4 } & $\begin{array}{c}\text { Secondary } \\
\text { level }\end{array}$ & 37 & 61.7 \\
\cline { 2 - 4 } & Vocation level & 15 & 25.0 \\
\hline \multirow{4}{*}{$\begin{array}{c}\text { Pesidential } \\
\text { building }\end{array}$} & 18 & 30.0 \\
\cline { 2 - 4 } & $\begin{array}{c}\text { General } \\
\text { building }\end{array}$ & 34 & 56.7 \\
\cline { 2 - 4 } & $\begin{array}{c}\text { Infrastructure } \\
\text { project }\end{array}$ & 8 & 13.3 \\
\hline Profession & Worker & 8 & 13.3 \\
\hline
\end{tabular}




\begin{tabular}{||c|c|c|c|}
\hline \multirow{1}{*}{} & Painter & 2 & 3.3 \\
\cline { 2 - 4 } & $\begin{array}{c}\text { Electrical } \\
\text { technician }\end{array}$ & 3 & 5.0 \\
\cline { 2 - 4 } & Tile technician & 3 & 5.0 \\
\cline { 2 - 4 } & $\begin{array}{c}\text { Shuttering } \\
\text { technician }\end{array}$ & 11 & 18.3 \\
\cline { 2 - 4 } & Mason & 5 & 8.3 \\
\cline { 2 - 4 } & $\begin{array}{c}\text { Plastering } \\
\text { technician }\end{array}$ & 3 & 5.0 \\
\cline { 2 - 4 } & $\begin{array}{c}\text { Sanitary / } \\
\text { mechanical } \\
\text { technician }\end{array}$ & 6 & 10 \\
\cline { 2 - 4 } & Other & 19 & 31.7 \\
\hline
\end{tabular}

Table 1. shows that majority of respondents are males with proportion $100 \%$, and proportion of females from respondent's is $0 \%$. The absence of females in construction works related to local habits and traditions in Gaza. Also, it shall be noted that majority of respondents age is less than 25 years that is equal $38.3 \%$ from total respondents, and $30 \%$ of respondents age is $25-30$, and $16.7 \%$ of respondents age is $30-40,15 \%$ of respondents age is more than 40 . Furthermore, data collected demonstrate that field's experience for $38.3 \%$ of respondents is less than 5 years, experience is $5-10$ years for $28.3 \%$ of respondents, $10 \%$ of respondents have 10-15 years of field's experience, $23.3 \%$ of respondent's experience is more than 15 years.

Table 1. shows that $1.7 \%$ of respondents are uneducated. Education level is primary for $11.7 \%$ of respondents, Education level is secondary for $61.7 \%$ of respondents, $25 \%$ of respondents have a vocation level of education. $30 \%$ of respondents work in residential projects. $56.7 \%$ of respondents, work in general building projects, $13.3 \%$ of respondents work in infrastructure projects.

Distribution of the profession of the questioned person shows that majority of respondents work as shuttering technician and that form $18.3 \%$ of respondents, $13.3 \%$ of respondents work as workers, $3.3 \%$ of respondents work as painters, $5 \%$ of respondents work as tile technicians in addition to as electrical technicians, $8.3 \%$ of respondents work as masons, $5 \%$ of respondents work as plastering technicians.

Table 2. Reasons of dissatisfaction for worker

\begin{tabular}{|c|c|c|c|c|c|c|}
\hline Item & Mean & S.D & RII\% & $\begin{array}{c}\text { Test } \\
\text { value }\end{array}$ & $\begin{array}{c}\text { P- } \\
\text { value }\end{array}$ & Rank \\
\hline Work hours exceeds the standard period ( 8 hours). & 3.93 & 1.12 & 78.7 & 6.467 & 0.000 & 2 \\
\hline I feel good about my monthly salary. & 2.82 & 1.24 & 56.3 & -1.144 & 0.257 & 13 \\
\hline $\begin{array}{l}\text { The possibility for workers to increase their skills in the future, such } \\
\text { as training and education by the employer. }\end{array}$ & 3.87 & 1.14 & 77.3 & 5.879 & 0.000 & 3 \\
\hline The administration approves pension / sick leave / insurances & 2.42 & 1.33 & 48.3 & -3.394 & 0.001 & 15 \\
\hline $\begin{array}{l}\text { Improving the existing conditions surrounding the work site, such as } \\
\text { transportation roads, security matters, and social issues }\end{array}$ & 3.58 & 1.2 & 71.7 & 3.774 & 0.000 & 6 \\
\hline $\begin{array}{l}\text { The administration adopts the system in place for vacations and } \\
\text { holidays }\end{array}$ & 2.98 & 1.37 & 59.7 & -0.094 & 0.925 & 12 \\
\hline $\begin{array}{l}\text { The lack of skill of the technical assistants at work, and their } \\
\text { confusion in the work }\end{array}$ & 3.12 & 1.22 & 62.3 & 0.739 & 0.463 & 11 \\
\hline The workers' lack of job security and constant fear of being fired & 3.63 & 1.38 & 72.7 & 3.562 & 0.001 & 5 \\
\hline $\begin{array}{l}\text { The management adopts principles of friendship, intimacy, } \\
\text { solidarity and affection with employees }\end{array}$ & 4.10 & 1.24 & 82.0 & 6.846 & 0.000 & 1 \\
\hline Good treatment of supervisors at work to workers & 3.73 & 1.35 & 74.7 & 4.204 & 0.000 & 4 \\
\hline Delay by the employer in paying workers' dues on time & 3.15 & 1.59 & 63.0 & 0.730 & 0.469 & 10 \\
\hline $\begin{array}{l}\text { The lack of continuity of work in the sites, which causes confusion } \\
\text { in the priorities of workers }\end{array}$ & 3.43 & 1.36 & 68.7 & 2.473 & 0.016 & 7 \\
\hline $\begin{array}{l}\text { The large number of workers on the work site and causing } \\
\text { confusion in the work }\end{array}$ & 3.27 & 1.42 & 65.3 & 1.450 & 0.152 & 8 \\
\hline Switch supervisors to work for less qualified people & 2.73 & 1.45 & 54.7 & -1.426 & 0.159 & 14 \\
\hline The volume of work on site exceeds the manpower of the workers & 3.23 & 1.31 & 64.7 & 1.383 & 0.172 & 9 \\
\hline All items of the field & 3.33 & 0.50 & 66.7 & 5.157 & 0.000 & \\
\hline
\end{tabular}

Table 2. shows that the mean of item \#6 "The management adopts principles of friendship, intimacy, solidarity and affection with employees" equals $4.10(82 \%)$, Test-value $=6.846$, and P-value is 0.000 . It is concluded that the respondents agreed to this item. The mean of item \#4 "The administration approves pension / sick leave / insurances" equals $2.42(48.3 \%)$, Test-value $=-3.394$, and $\mathrm{P}$-value $=0.001$. which is at the level of significance 0.05 . It is concluded that the respondents disagreed to this item. The mean of the total equals $3.33(66.7 \%)$, Test-value = 5.157, and P-value less than 0.000. The sign of the test is 
positive, it is concluded that the respondents agreed to this field.

Table 3. shows that the mean of item \#4 "The management provides safety measures for human resources when carrying out hazardous work" equals 4.37 (87.3\%), Test-value $=10.170$, and $\mathrm{P}=0.000$. It is concluded that the respondents agreed to this item. The mean of item \#5 "The

Table 3. Health and Safety in working environmental conditions that workers are exposed to on the site (extreme heat, rain, storms)" equals 3.82 (76.3\%), Testvalue $=5.399$, and $\mathrm{P}$-value $=0.000$. which is at the level of significance 0.05 . It is concluded that the respondents agreed to this item. The mean of the total equals 4.05 $(80.9 \%)$, Test-value $=10.949$, and P-value less than 0.000 . The sign of the test is positive, so the mean of this field is significantly at 0.05 .

\begin{tabular}{|c|c|c|c|c|c|c|}
\hline Item & Mean & S.D & RII\% & $\begin{array}{c}\text { Test } \\
\text { value }\end{array}$ & $\begin{array}{c}\text { P- } \\
\text { value }\end{array}$ & Rank \\
\hline $\begin{array}{l}\text { The management is obligated to take safety measures for its human } \\
\text { resources and follow them }\end{array}$ & 3.92 & 1.31 & 78.3 & 5.438 & 0.002 & 4 \\
\hline The management provides protective clothing to human resources & 3.97 & 1.19 & 79.3 & 6.278 & 0.000 & 3 \\
\hline $\begin{array}{l}\text { The administration does not allow any narcotic drugs / tramadol to } \\
\text { be at work }\end{array}$ & 4.17 & 1.39 & 83.3 & 6.492 & 0.000 & 2 \\
\hline $\begin{array}{l}\text { The management provides safety measures for human resources } \\
\text { when carrying out hazardous work }\end{array}$ & 4.37 & 1.04 & 87.3 & 10.170 & 0.000 & 1 \\
\hline $\begin{array}{l}\text { The environmental conditions that workers are exposed to on the } \\
\text { site (extreme heat, rain, storms) }\end{array}$ & 3.82 & 1.17 & 76.3 & 5.399 & 0.000 & 5 \\
\hline All items of the field & 3.33 & 0.50 & 66.7 & 5.157 & 0.000 & \\
\hline
\end{tabular}

Table 4. shows that the mean of all items equal 3.51 $(70.2 \%)$, Test-value $=8.355$, and $\mathrm{P}=0.000$, It is concluded that the respondents agreed to all items of questionnaire. Also from table 4, it shows that "Health and Safety in construction work" was ranked in the first position by fields with RII of (80.9\%) and followed by "Reasons for dissatisfaction of construction workers" with (66.7\%).

Table 4. Mean and test values for "All items of questionnaire"

\begin{tabular}{|c|c|c|c|c|c|c|}
\hline Item & Mean & S.D & RII\% & $\begin{array}{c}\text { Test } \\
\text { value }\end{array}$ & $\begin{array}{c}\text { P- } \\
\text { value }\end{array}$ & Rank \\
\hline Reasons for dissatisfaction of construction workers & 3.33 & 0.50 & 66.7 & 5.157 & 0.000 & 2 \\
\hline Health and Safety in construction work & 4.05 & 0.74 & 80.9 & 10.949 & 0.000 & 1 \\
\hline All items of all items & 3.51 & 0.47 & 70.2 & 8.355 & 0.000 & \\
\hline
\end{tabular}

\section{CONCLUSIONS}

Human resources are considered one of the most important resources affecting quality in the construction sector. Hence, Employees in the construction industry must be maintained and developed. Human resource development gives the organization a competitive advantage. However, ignoring it negatively affects the quality of the company's future projects. This research work addressed the topic of health and safety in the construction sector and the role of human resources. As it was shown that workers in the workplace are exposed to various weather conditions, we recommend the need to provide protection and prevention methods and ways during work to avoid the risks that may result from that. The research also showed a lack of sufficient commitment by the administration to safety procedures for its human resources, which contributes to the occurrence of injuries and hazards for workers and makes them periodically common, which has adverse effects on productivity and work quality. Although the institution provides protective clothing for human resources and prevents the use of drugs during working hours. Providing safety procedures for human resources at work sites for workers and employees helps reduce injuries and risks that may be caused by the absence of this. There is a need for the government to enact appropriate legislation to enforce on all companies operating in construction sector to providing equipment of safety and health for workers in work environments and sites. It also shows the importance of demanding health and safety policies and provisions from civil society and workers in the construction sector. The need to pay attention to the training aspect of workers, as it contributes to reducing potential accidents. 


\section{CONFLICT OF INTEREST STATEMENT}

The authors declare that there is no conflict of interest.

\section{REFERENCES}

[1] Ahmad, S., \& Schroeder, R. G. (2003). The impact of human resource management practices on operational performance: recognizing country and industry differences. Journal of operations Management, 21(1), 19-43. https://doi.org/10.1016/S0272-6963(02)00056-6

[2] Armstrong, M. (2006). Human resource management practice 10th ed. Kogan page publisher.

[3] Bontis, N., Dragonetti, N. C., Jacobsen, K., \& Roos, G. (1999). The knowledge toolbox: A review of the tools available to measure and manage intangible resources. European management journal, 17(4), 391402.

https://doi.org/10.1016/S0263-2373(99)00019-5

[4] Cooper, M., \& Cotton, D. (2000). Safety training-a special case? Journal of European Industrial Training.

[5] Cox, S., \& Cox, T. (1996). Safety, systems, and people. Butterworth-Heinemann.

[6] Davies, V. J., \& Tomasin, K. (1996). Construction safety handbook. Thomas Telford.

[7] Gberevbie, D. E. (2012). Impact of human resource development and organizational commitment on financial sector employees in Nigeria. Analele Ştiinţifice ale Universităţii» Alexandru Ioan Cuza «din Iași. Stiiinte economice, 59(2), 29-41.

[8] Hamid, A. R. A., Abd Majid, M. Z., \& Singh, B. (2008). Causes of accidents at construction sites. Malaysian journal of civil engineering, 20(2). https://doi.org/10.11113/mjce.v20.15769

[9] Jannadi, O. A., \& Bu-Khamsin, M. S. (2002). Safety factors considered by industrial contractors in Saudi Arabia. Building and Environment, 37(5), 539-547. https://doi.org/10.1016/S0360-1323(01)00056-7

[10] Kartam, N. A., \& Bouz, R. G. (1998). Fatalities and injuries in the Kuwaiti construction industry. Accident analysis \& prevention, 30(6), 805-814. https://doi.org/10.1016/S0001-4575(98)00033-5

[11] Khalid, A. G. (1996). Construction site injuries: The case of Malaysia. In Implementation of Safety and Health on Construction Sites, Proceedings of the First International Conference of CIB Working Commission $W$ (Vol. 99, pp. 93-102).

[12] Kheni, N. A., Dainty, A. R., \& Gibb, A. (2008). Health and safety management in developing countries: a study of construction SMEs in Ghana. Construction Management and Economics, 26(11), 1159-1169. https://doi.org/10.1080/01446190802459916
[13] Law, W. K., Chan, A. H. S., \& Pun, K. F. (2006). Prioritising the safety management elements: a hierarchical analysis for manufacturing enterprises. Industrial Management \& Data Systems. https://doi.org/10.1108/02635570610671470

[14] Levitt, R. E., \& Samelson, N. M. (1993). Construction safety management. John Wiley \& Sons.

[15] Lin, J., \& Mills, A. (2001). Measuring the occupational health and safety performance of construction companies in Australia. Facilities.

[16] Madter, N., Bower, D. A., \& Aritua, B. (2012). Projects and personalities: A framework for individualising project management career development in the construction industry. International Journal of Project Management, 30(3), 273-281. https://doi.org/10.1016/j.ijproman.2011.09.001

[17] Nassazi, A. (2013). Effects Of Training On Employee Performance.: Evidence from Uganda.

[18] Ng, S. T., Cheng, K. P., \& Skitmore, R. M. (2005). A framework for evaluating the safety performance of construction contractors. Building and environment, 40(10), 1347-1355. https://doi.org/10.1016/j.buildenv.2004.11.025

[19] Rantanen, J., \& Fedotov, I. (1998). Occupational health services. Encyclopaedia of Occupational Health and Safety, 4th edn. Geneva: ILO, 16-1.

[20] Shehzad, A., \& Akhtar, M. M. (2012). Development of scale to assess effective execution of human resource practices for general public sector universities. International Journal of Applied Science and Technology, 211-223.

[21] Swanson, R. A., Holton, E., \& Holton, E. F. (2001). Foundations of human resource development. Berrett-Koehler Publishers.

[22] Tabassi, A. A., Ramli, M., \& Bakar, A. H. A. (2011). Training, motivation and teamwork improvement: The case of construction firms. African journal of business management, 5(14), 5627-5636. https://doi.org/10.5897/AJBM10.1343

[23] Umrani, W. A., Mahmood, R., \& Ahmed, U. (2016). Unveiling the Direct Effect of Corporate Entrepreneurship's Dimensions on the Business Performance: A Case of Big Five Banks in Pakistan. Studies in Business \& Economics, 11(1). https://doi.org/10.1515/sbe-2016-0015

[24] Uzondu, C. C. (2013). Evaluation of human resource management practices on the productivity and performance of transport organizations in Nigeria. IOSR Journal of Business and Management, 12(59-70).

[25] Yip, B., Rowlinson, S., Kvan, T., \& Lingard, H. (2005, February). Job burnout within the Hong Kong construction industry: A cultural perspective. In Proceedings of the CIB W92/T23/W107 International Symposium on Procurement Systems (pp. 8-10). 